Dept. of Food Hygiene, Port-Said Lab.,

Animal Health Research Institute, Dokki, Giza, Egypt.

\title{
THE INCIDENCE OF PROTEOLYTIC PSEUDOMONAS SPECIES ASSOCIATED WITH GROUND BEEF WITH REGARDS TO THEIR SPOILAGE EFFECT
}

(With 5 Tables)

By

\section{H.E.M. FARAG and NAHLA T. KORASHY*}

*Dept. of Microbiology, Port-Said Lab., Animal Health Research Institute,

Dokki, Giza, Egypt.

(Received at 10/9/2008)

نسبة تواجد ميكروبات السودوموناس المحلة للبروتين في اللحم البقري المفروم مع الإثارة إلي تأثيرهات الماتلة للفساد

\section{حسن السبا محد فرج ، نـلية طه عبل الجواد قرشي}

في در اسة لتحديد مدي وجود ميكروبات السودوموناس في اللحم البقري المفروم تم فحص

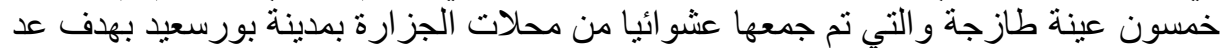

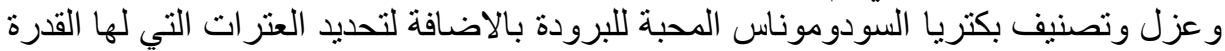

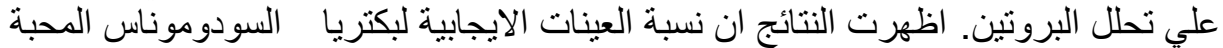

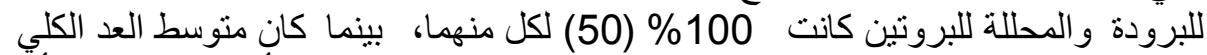

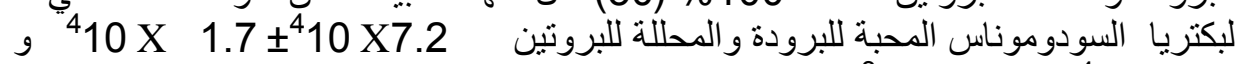

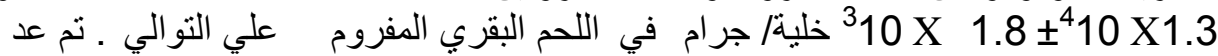

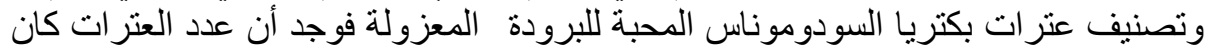

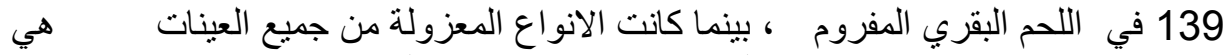

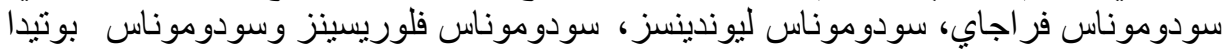

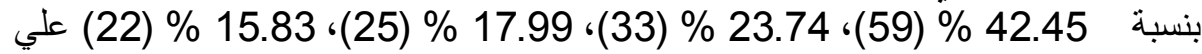

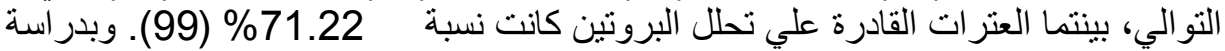

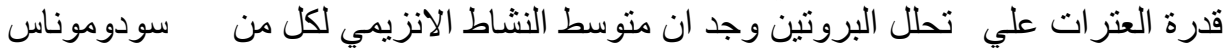

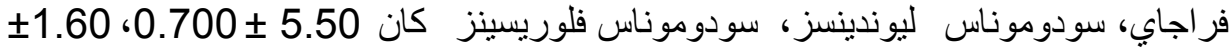

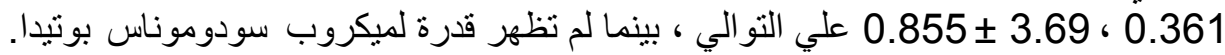

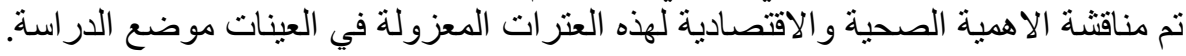


Fifty fresh samples of ground beef were randomly purchased from butchers shops from Port-Said city. The samples were examined for enumeration of the total psychrotrophic and proteolytic Pseudomonas counts with studying the proteolytic activity of the isolated strains. The incidence of positive samples for total psychrotrophic and proteolytic Pseudomonas were $100 \%(\mathrm{n}=50)$ for each, while the mean values of the total psychrotrophic and proteolytic Pseudomonas counts were $7.2 \times 10^{4}$ $\pm 1.7 \times 10^{4}$ and $1.3 \times 10^{4} \pm 1.8 \times 10^{3} \mathrm{CFU} / \mathrm{g}$ of ground beef respectively. Most of total psychrotrophic and proteolytic Pseudomonas counts ranged from $10^{3}$ to $<10^{6} \mathrm{CFU} / \mathrm{g}$ of ground beef. 139 psychrotrophic Pseudomonas strains isolated from the examined samples were identified as Pseudomonas fragi (Cluster II), Pseudomonas lundensis (Cluster IV), Pseudomonas fluorescens (Cluster II) and Pseudomonas putida (Cluster II) with an incidence of 59 (42.45\%), 33 (23.74\%), 25 $(17.99 \%)$ and $22(15.83 \%)$ respectively while the 99 proteolytic strains constituted $50(50.51 \%), 29(29.29 \%), 20(20.20 \%)$ and $0.0(0.00 \%)$ for the aforesaid strains respectively. The proteolytic activity of the isolates in the examined samples were $5.50 \pm 0.700,1.60 \pm 0.361$ and $3.69 \pm$ 0.855 for Pseudomonas fragi (Cluster II), Pseudomonas lundensis (Cluster IV) and Pseudomonas fluorescens (Cluster II) while that of Pseudomonas putida (Cluster II) could not be detected. The public health and economic significance of isolated strains were discussed.

Key words: Pseudomonas, meat products, ground beef.

\section{INTRODUCTION}

Meat is one of the most perishable foods owing to its palatability, abundance of important nutrients of highly nutritive value and high water content therefore its composition is ideal for the growth and activity of a wide range of spoilage bacteria (Labadie, 1999; Gram et al., 2002; Mayer et al., 2003).

A very heterogeneous bacterial flora can colonize the meat surface through different stages involving adsorption to the meat surface (Chung et al., 1989) by glycocalex (Costerson et al., 1981). Thus meat tissue surface carry considerable bacterial loads (Upmann et al., 2000). These bacteria are distributed throughout the entire product during grinding and mixing processes used in fabrication of ground meat (Rice et al., 1997). The composition of the minced meat spoilage flora is greatly influenced by the storage conditions such as temperature and type of packaging (Tsigarida and Nychas, 2001; Ercolini, 2004). 
The principle causative agents responsible for spoilage of fresh meat products during aerobic storage are several Pseudomonas species (Widders et al., 1995; Borch et al., 1996; Gill, 2003) which represent the most psychrotrophic bacteria (Gill and Newton, 1982) and involve members of Pseudomonas fluorescent group and psychrotrophic P. fragi, P. lundensis and P. putida (Gill, 2003):

Genus Pseudomonas is ubiquitous microorganism widely distributed in nature and can use a variety of non-carbohydrates compounds for energy nature. They are Gram -ve, catalse +ve, rods shaped, non-spore forming and motile by one or several polar flagella (Krieg, 1984; Gennari and Dragotto, 1992).

They have a metabolic diversity and ability to grow to high number during refrigerated storage (Gennari and Dragotto, 1992), depend upon extracellular and/or cell associated heat-stable extracellular proteases (highly proteolytic) enzyme systems to liberate protein bound amino acids for assimilation and metabolic processes (Cousin, 1982; Chróst, 1991) leading to biological changes in the composition of meat and its products (Gill and Newton, 1982). These enzymes remain active even following thermal processing steps that can destroy the organisms producing theses enzymes (Cousin, 1982; Sorhaug and Stepaniak, 1997).

These types of bacteria cannot assimilate proteins directly (Payne and Smith, 1994) but firstly has the capability for glucose and amino acid degradation and utilization for its activity even at refrigerated temperature until the release of undesired volatile nitrogenous metabolites such as ammonia and dimethylsulfide (Lerke et al., 1967; Stanbridge and Davies, 1998; Koutsoumanis et al., 2006).

Some species of Pseudomonas such as P. fragi cause an increase in the water soluble and non protein nitrogen content of muscle and a decrease in both the salt-soluble and insoluble protein content (Borton, et al., 1970) causing certain metabolic changes (Tarrant, et al., 1971) and deterioration in quality of meat consequently organoleptic changes in appearance and odor during prolonged storage (Farber and Idziak, 1984). Some species like $P$. fragi and $P$. fluorescence cause fruity and putrid odorous beef (Dainty et al., 1989; Ryan and Ray, 2004). Also $P$. fragi have deleterious effect on the color of meat stored at $1{ }^{\circ} \mathrm{C}$ resulting in a green and slimy appearance (Bala et al., 1977). Also a significant number of Pseudomonas species can produce exopolysaccharides that are known as slime layered which contribute to the surface make the products undesirable for human consumption (Jay, 2000) leading to lowering the shelf-life of refrigerated meat (Tarrant, 
et al., 1971) as a result of the growth of microorganisms to unacceptable levels (Jay, 2000).

Besides these bacterial spoilage cause a significant economic losses for the meat industry (Cousin, 1982). Some Pseudomonas species has been recognized as an infectious agent transmitted by food and water affecting primarily immunecompromised people and those suffering from cystic fibrosis (Morais, et al., 1997) leads to several outbreaks of food poisoning (Pererra et al., 1977). On the other hand Pseudomonas fluorescence can also enhance the growth of nonpathogenic and pathogenic bacteria (Gabriel-Piette and Idziak, 1991).

The purpose of this study aimed to determine psychrophilic Pseudomonas count and its proteolytic activity in ground beef as an indication for pre-spoilage of ground meat as well as its keeping quality.

\section{MATERIALS and METHODS}

\section{1: Samples collection:}

A total of 50 random samples of fresh ground meat (200 g each) were purchased from Port-Said butcher's shops. Each individual sample was placed separately into sealed sterile plastic bag, thoroughly identified and delivered to the laboratory in a refrigerated container. All specimens were processed within 4 hours of collection for counting, isolation and identification of psychrotrophic Pseudomonas with studying of their proteolytic activity.

\section{2: Bacteriological examination:}

\section{2-1: Enumeration of psychrotrophic Pseudomonas species:}

\section{2-1-1: Preparation and enrichment of samples:}

A representative $25 \mathrm{~g}$ of each ground meat sample were taken aseptically and homogenized by blending at 10,000-12,000 rpm for 2 minutes in $225 \mathrm{ml}$ of $0.1 \%$ peptone water with salt $(\mathrm{Na} \mathrm{Cl}, 0.85 \%$ "wt/vol"). Then tenfold serial dilution was prepared using $0.1 \%$ peptone water till dilution $10^{6}$ according to Mead and Adams (1977).

\section{2-1-2: Isolation and enumeration of psychrotrophic Pseudomonas species:}

$0.1 \mathrm{ml}$ of each dilution of meat homogenate was spread on the surface of a separate, marked petri plate of CFC (cetramid, fucidin cephaloridine) agar media. Immediately sample dilutions were spread thoroughly and uniformly allover the solid media. All plates were inverted and incubated at $20^{\circ} \mathrm{C}$ for 2 days for screening of psychrotrophic Pseudomonas species. Plates containing 30-300 colonies were counted and the Pseudomonas count as number of organisms/g of 
ground meat was calculated according to Harrigan and McCance (1966) and Mead and Adams (1977).

\section{2-1-3: Purification of the isolates:}

Suspected colonies were purified by streaking onto slope of nutrient agar and incubated at $4{ }^{\circ} \mathrm{C}$ for 3-5 days according to Harrigan and McCance (1966) and Mead and Adams (1977) for morphological and biochemical identification of the isolates and proteolytic activity screening of each isolates

\section{3: Morphological and biochemical identification of the isolates:}

The isolates were morphologically and biochemically identified by Gram stain, oxidase test, catalase test, motility, carbohydrates fermentation and other biochemical tests according to Stanier et al. (1966), Sneath and Sokal (1973), Molin and Ternstrom (1982) Cowan, et al. (1993) and Palleroni (1993).

\section{4: Enumeration of proteolytic Pseudomonas species:}

Thoroughly and uniformly another $0.1 \mathrm{ml}$ of each dilution of meat homogenate was spread on the surface of a separate, marked petri plates of plate count agar "PCA" containing $1 \%$ skim milk powder (skim milk agar). All plates were inverted and incubated at $30^{\circ} \mathrm{C}$ for $72 \mathrm{~h}$. Colonies showing proteolytic activity were counted and recorded and the proteolytic Pseudomonas count as number of organisms/g of ground meat was calculated according to Marshall (1993).

\section{5: Screening of proteolytic activity:}

Single Pseudomonas colonies were streaked on plate count agar "PCA" containing 1\% skim milk powder (skim milk agar) for screening the production of extracellular proteolytic enzymes. Then the plates were incubation at $30^{\circ} \mathrm{C}$ for $72 \mathrm{~h}$. Plates were flooded by $1 \mathrm{~N} \mathrm{HCl}$ for observation of clearance zones formed by protease positive strains. For each isolate, clearance zones diameter to the colony diameter was calculated. The assay was repeated at least three times and the mean ratios and standard deviation were reported according to Mead and Adams (1977), Frank et al. (1992) and Vanderzant and Splittstoesser (1992).

\section{6- Statistical methods:}

Minimum, maximum, mean, standard deviation and standard error of mean were used to describe data.

These tests were analysed on a compatible personal computer using the Statistical Package for Social scientists (SPSS) for windows 12.0 (SPSS Inc., Chicago, IL, and USA).

\section{RESULTS}


Table 1: Statistical analytical results of the total psychrotrophic and proteolytic Pseudomonas counts (CFU/g) recovered from ground beef samples.

\begin{tabular}{|c|c|c|c|}
\hline & & $\begin{array}{c}\text { Total psychrotrophic } \\
\text { Pseudomonas }\end{array}$ & $\begin{array}{c}\text { Proteolytic } \\
\text { Pseudomonas }\end{array}$ \\
\hline No. of sa & ples & 50 & 50 \\
\hline Positive & No. & 50 & 50 \\
\hline samples & $\%$ & 100 & 100 \\
\hline & Min. & $4.0 \times 10^{2}$ & $3.0 \times 10^{2}$ \\
\hline & Max. & $5.2 \times 10^{5}$ & $4.5 \times 10^{4}$ \\
\hline . & Mean & $7.2 \times 10^{4}$ & $1.3 \times 10^{4}$ \\
\hline 㖊 & S.E. & $1.7 \times 10^{4}$ & $1.8 \times 10^{3}$ \\
\hline \pm 0 & S.D. & $1.2 \times 10^{5}$ & $1.3 \times 10^{4}$ \\
\hline
\end{tabular}

Min. $=$ Minimum. Max. $=$ Maximum. $\mathrm{SE}=$ Standard Error $\mathrm{SD}=$ Standard Deviation * Significant at $\mathrm{P}<0.05$ and $\mathrm{P}<0.01$ using t-test

Table 2: Frequency distribution of the examined ground beef based on their total psychrotrophic and proteolytic Pseudomonas counts $(\mathrm{n}=50)$

\begin{tabular}{|l|c|c|c|c|}
\hline \multirow{2}{*}{ Count range } & \multicolumn{2}{|c|}{$\begin{array}{c}\text { Total psychrotrophic } \\
\text { Pseudomonas }\end{array}$} & \multicolumn{2}{c|}{ Proteolytic Pseudomonas } \\
\cline { 2 - 5 } & No. & $\%$ & No. & $\%$ \\
\hline$<10^{3}$ & 2 & 4.00 & 3 & 6.00 \\
\hline $10^{3}-<10^{4}$ & 19 & 38.00 & 24 & 48.00 \\
\hline $10^{4}-<10^{5}$ & 18 & 36.00 & 23 & 46.00 \\
\hline $10^{5}-<10^{6}$ & 11 & 22.00 & 0.00 & 0.00 \\
\hline Total & 50.00 & 100.00 & 50.00 & 50.00 \\
\hline
\end{tabular}

Table 3: Incidence of psychrotrophic and proteolytic Pseudomonas species recovered from ground beef.

\begin{tabular}{|c|c|c|c|c|}
\hline \multirow[t]{2}{*}{ Pseudomonas species } & \multicolumn{2}{|c|}{$\begin{array}{l}\text { Psychrotrophic } \\
\text { Pseudomonas }\end{array}$} & \multicolumn{2}{|c|}{ Proteolytic Pseudomonas } \\
\hline & No. & $\%$ & No. & $\%$ \\
\hline Pseudomonas fragi (Cluster II) & 59 & 42.45 & 50 & 50.51 \\
\hline Pseudomonas lundensis (Cluster IV) & 33 & 23.74 & 29 & 29.29 \\
\hline Pseudomonas fluorescens (Cluster II) & 25 & 17.99 & 20 & 20.20 \\
\hline Pseudomonas putida (Cluster II) & 22 & 15.83 & 0 & 00.00 \\
\hline Total & 139 & 100.00 & 99 & 100.00 \\
\hline
\end{tabular}

Table 4: Incidence of proteolytic activity grade of Pseudomonas species recovered from ground beef. 


\begin{tabular}{|c|c|c|c|c|c|c|c|c|}
\hline \multirow{4}{*}{ Pseudomonas species } & \multicolumn{6}{|c|}{ Proteolytic Activity Grade } & \multirow{3}{*}{\multicolumn{2}{|c|}{ Total }} \\
\hline & \multirow{2}{*}{\multicolumn{2}{|c|}{-ve }} & \multicolumn{4}{|c|}{$+\mathrm{ve}$} & & \\
\hline & & & \multicolumn{2}{|c|}{ Grade I } & \multicolumn{2}{|c|}{ Grade II } & & \\
\hline & No. & $\%$ & No. & $\%$ & No. & $\%$ & No. & $\%$ \\
\hline $\begin{array}{l}\text { 1-Pseudomonas fragi } \\
\text { (Cluster II) }\end{array}$ & ----- & ----- & ----- & ----- & 59 & 42.45 & 59 & 42.45 \\
\hline $\begin{array}{l}\text { 2-Pseudomonas lundensis } \\
\text { (Cluster IV) }\end{array}$ & ----- & ----- & 33 & 23.74 & ----- & ----- & 33 & 23.74 \\
\hline $\begin{array}{l}\text { 3-Pseudomonas fluorescens } \\
\text { (Cluster II) }\end{array}$ & ----- & ----- & 14 & 10.07 & 11 & 7.91 & 25 & 17.99 \\
\hline $\begin{array}{l}\text { 4-Pseudomonas putida } \\
\text { (Cluster II) }\end{array}$ & 22 & 15.83 & ----- & ----- & ----- & ----- & 22 & 15.83 \\
\hline Total & 22 & 15.83 & 47 & 33.81 & 70 & 50.36 & 139 & 100.0 \\
\hline
\end{tabular}

-ve $=$ No visible halo, $\quad+=1-2 \mathrm{~mm}$ visible proteolysis,

$++=$ More than $2 \mathrm{~mm}$ visible proteolysis from the margin of colony.

Table 5: Statistical analytical results of the proteases activity of the isolated Pseudomonas species recovered from ground beef samples.

\begin{tabular}{|c|c|c|c|c|}
\hline & \multicolumn{4}{|c|}{ Isolated strain } \\
\hline & $\begin{array}{c}\text { Pseudomonas } \\
\text { fragi } \\
\text { (Cluster II) }\end{array}$ & $\begin{array}{c}\text { Pseudomonas } \\
\text { lundensis } \\
\text { (Cluster IV) }\end{array}$ & $\begin{array}{c}\text { Pseudomonas } \\
\text { fluorescens } \\
\text { (Cluster II) }\end{array}$ & $\begin{array}{c}\text { Pseudomonas } \\
\text { putida } \\
\text { (Cluster II) }\end{array}$ \\
\hline No. of samples & 59 & 33 & 25 & 22 \\
\hline Min. & 3.50 & 0.90 & 1.70 & ND \\
\hline Max. & 7.00 & 2.00 & 5.00 & ND \\
\hline Mean & 5.50 & 1.60 & 3.69 & ND \\
\hline S.E. & 0.091 & 0.063 & 0.171 & ND \\
\hline S.D. & 0.700 & 0.361 & 0.855 & ND \\
\hline
\end{tabular}

$\mathrm{ND}=$ not detected

Proteases activity \pm standard deviations are reported as: Mean ration reflecting proteases activity $=$ clearance zone diameter/ colony size

\section{DISCUSSION}

Many flora of spoilage bacteria have an effect on the shelf life of refrigerated food products. The main flora responsible for spoilage of fresh meat products during aerobic storage belong to genus Pseudomonas (Widders et al., 1995). This genus include more than 140 species and represents the most psychrotrophic bacteria which are highly proteolytic and/or strong lipolytic and lead to biological changes in the 
composition of meat and meat products particularly at low temperature (Gill and Newton 1982).

The results given in Table (1) revealed that the incidence of positive samples for total psychrotrophic and proteolytic Pseudomonas were $100 \%$ for each, while the mean values of the total psychrotrophic and proteolytic Pseudomonas counts were $7.2 \times 10^{4} \pm 1.7 \times 10^{4}$ and $1.3 \times 10^{4} \pm 1.8 \times 10^{3} \mathrm{CFU} / \mathrm{g}$ of ground beef respectively. These results were lower than the results recorded by Mayer, et al. (2003) and Ercolini, et al. (2007) but higher than the results recorded by Widders, et al. (1995) and Ercolini, et al. (2006). The high figures of our results may be attributed to the initial microbial loads of the samples (Emswiler, et al., 1976 and Upmann et al., 2000) and to the variation in the time/temperature storage condition (Ercolini, et al., 2006), $\mathrm{pH}, \mathrm{O}_{2}$ availability and other bacterial flora (Gram, et al., 2002).

The frequency distribution of the total psychrotrophic and proteolytic Pseudomonas counts of the examined ground beef samples presented in Table (2) showed that most of the total psychrotrophic and proteolytic Pseudomonas counts within the range of $10^{3}-<10^{6}$ and $10^{3}-$ $<10^{5} \mathrm{CFU} / \mathrm{g}$ with an incidence $96 \%$ and $94 \%$ respectively. Meanwhile $4 \%$ of total psychrotrophic counts and $6 \%$ of proteolytic Pseudomonas counts were less than $<10^{3} \mathrm{CFU} / \mathrm{g}$ in the examined samples. At these levels of no organoleptic changes and no sings of spoilage in the examined samples could be detected which agree with the results recorded by Jay (2000) and Eriksson et al. (1995) who reported that the signs of spoilage appear in counts more than $10^{6} \mathrm{CFU} / \mathrm{g}$ food.

The obtained results in Table (3) revealed that 139 psychrotrophic and 99 proteolytic Pseudomonas isolates were recovered from the examined ground beef samples. The psychrotrophic Pseudomonas isolates were identified as Pseudomonas fragi (Cluster II), Pseudomonas lundensis (Cluster IV), Pseudomonas fluorescens (Cluster II) and Pseudomonas putida (Cluster II) with an incidence of $42.45 \%, 23.74 \%, 17.99 \%$ and $15.83 \%$ respectively. While the proteolytic Pseudomonas isolates were identified as Pseudomonas fragi (Cluster II), Pseudomonas lundensis (Cluster IV), Pseudomonas fluorescens (Cluster II) and Pseudomonas putida (Cluster II) with an incidence of $50.51 \%, 29 \%, 20.20 \%$ and $0 \%$ respectively.

The predominant of Pseudomonas fragi (Cluster II) over Pseudomonas lundensis (Cluster IV) and Pseudomonas fluorescens (Cluster II) is due to its ability to metabolize creatine and creatinine under aerobic conditions (Drosinos and Board, 1994) and the shorter of its lag phase than the others strain (Gennari and Dragotto, 1992). Thus 
Pseudomonas fragi (Cluster II) accepted as the principle aerobic gram negative spoilage organism at chill temperatures (Banks and Board, 1983), while Pseudomonas lundensis (Cluster IV) and Pseudomonas fluorescens (Cluster II) constitute a significant part of the spoilage microflora on chill meat under aerobic conditions (Prieto et al., 1992). On the other hand Pseudomonas putida (Cluster II) has ability to degrade toluene (Marqués and Ramos, 1993) needed for the activity of spoilage bacteria. The variation in the number of Pseudomonas fragi (Cluster II), Pseudomonas lundensis (Cluster IV) and Pseudomonas fluorescens (Cluster II) between psychrotrophic and proteolytic Pseudomonas was attributed to the difference in the media and temperature of incubation (Gram et al., 2002).

The results reported in Table (4) showed that 22 (15.83\%) of the isolated Pseudomonas strains showed no proteolytic activity and were identified as P. putida, while $33(23.74 \%)$ and $14(10.07 \%)$ of the examined isolates were of Grade I and were identified as Pseudomonas lundensis (Cluster IV) and Pseudomonas fluorescens respectively. On the other hand, Pseudomonas fragi $(42.45 \%)$ and some strains of Pseudomonas fluorescens (7.91\%) were of Grade II.

Regarding proteases activity of the proteolytic strains in Table (5), the mean values of the proteases activity of Pseudomonas fragi (Cluster II), Pseudomonas lundensis (Cluster IV) and Pseudomonas fluorescens (Cluster II) were 5.50 $\pm 0.700,1.60 \pm 0.361$ and $3.69 \pm$ 0.855 respectively. These results in addition to the count levels in Table (2) agree with the results reported by Cousin (1982) who found that proteases enzymes have been detected at psychrotrophic counts of $10^{3}$ $<10^{6} \mathrm{CFU} / \mathrm{g}$ food.

Pseudomonas fragi (Cluster II) has the highest proteolytic activity followed by Pseudomonas fluorescens (Cluster II) due to its ability to produce extracellular proteases in the late lag or early stationary phases of the bacterial growth (Kohlmann et al., 1991 and Widders et al., 1995).

Psychrotrophic Pseudomonas grows at refrigerated storage temperature with a maximum growth within 3-4 days and detection of heat resistant proteases at counts of $10^{3}-10^{6} \mathrm{CFU} / \mathrm{g}$, (Cousin, 1982). Besides its ability to make unacceptable changes in the meat and meat products (Gram et al., 2002) and biofilms formation (Ryan and Ray, 2004). Therefore unsafe meat and meat products with lowering keeping quality will be produced. It is recommended that strict hygienic control measures should be applied before, during and after slaughtering, with a rapid and accurate detection system for microbial spoilage, good 
time/temperature storage besides prevention the cross and secondary contamination. Also strictly hygienic measurement for prevention and removal the source of pollution and biofilms with the control of the intrinsic and extrinsic ecological factors of meat ecosystem such as $\mathrm{pH}$, meat surface, $\mathrm{O}_{2}$ availability and temperature will produce safe meat and meat products for the consumers with high keeping quality.

\section{REFERENCES}

Bala, K.; Marshall, R.T.; Stringer, W.C. and Naumann, H.D. (1977): Effect of Pseudomonas fragi on the colour of beef. J. Food Sci. 42: 1176-1179.

Banks, J.G. and Board, R.G. (1983): The classification of Pseudomonads and others obligatory aerobic Gram-negative bacteria from British pork sausage and ingredients. Syst. Appl. Microbiol. 4: 424-438.

Borch, E.; Kant-Muermans, M.L. and Blixt, Y. (1996): Bacterial spoilage of meat and cured meat products. In. J. Food Microbiol. 33: 103-120

Borton, R.J.; Bratzler, L.J. and Price, J.F. (1970): Effects of four species of bacteria on porcine muscle. 2. Electrophoretic pattern of extracts of salt soluble protein. J. Food Sci. 34: 783-786

Chróst, R.J. (1991): Microbial ectoenzymes in aquatic environments, p. 47-78. In J. Overbeck and R.J. and molecular approaches. Springer-Verlag, New York, N.Y.

Chung, K.T.; Dickson, J.S. and Crouse, J.D. (1989): Attachment and proliferation of bacteria on meat. J. Food Prot. 52:173-177

Costerson, J.W.; Irvin, R.T. and Cheng, K.J. (1981): The bacterial glycocalex in nature and diseases. Annu. Rev. Microbiol. 35: 299-324

Cousin, M.A. (1982): Presence and activity of psychrotrophic microorganisms in milk and dairy products: a review. J. Food Prot. 45: 172-207.

Cowan, S.T.; Steel, K.J.; Barow, G.I. and Feltham, R.K.A. (1993): Characters of Gram-negative bacteria, p. 94-150. In G.I. Barrow and R.K.A. Feltham (ed.), Cowan and Steel's manual for the identification of medical bacteria, $3^{\text {rd }}$ ed. Cambridge University Press, London, United Kingdom.

Dainty, R.H.; Edwads, R.A.; Hibbard, C.M. and Marnewick, J.I. (1989): Volatile compounds associated with microbial growth on 
normal and high $\mathrm{pH}$ beef stored at chill temperature. J. Appl. Bactriol. 66: 281-289.

Drosinos, E.H. and Board, R.G. (1994): Metabolic activities of Pseudomonas in batch cultures in extract of minced lamb. J. Appl. Bacteriol. 77: 613-620.

Emswiler, B.; Pierson, C. and Kotula, A. (1976): Bacteriological quality and shelf life of ground beef. Appl. Environ. Microbiol. 31 (6): 826-830.

Ercolini, D. (2004): PCR-DGGE fingerprinting: novel strategies for detection of microbes in foods. J. Microbiol. Methods 56: 297-314.

Ercolini, D.; Russo, F.; Blaiotta, G.; Pepe, O.; Mauriello, G. and Villani, F. (2007): Simultaneous detection of Pseudomonas fragi, $P$. Lundensis and $P$. putida from meat by use of a multiplex PCR assay Targeting the caeA Gene. Appl. Environ. Microbiol. 73 (7): 2354-2359.

Ercolini, D.; Russo, F.; Torrieri, E.; Masi, P. and Villani, F. (2006): Changes in the spoilage related microbiota of beef during refrigerated storage under different package condition. Appl. Environ. Microbiol. 72 (7): 4663-4671.

Eriksson, P.V.; Paola, G.N.; Pasetti, M.F. and Manghi, M.A. (1995):

Inhibition energy-linked immunosorbent assay for detection of Pseudomonas fluorescens on meat surfaces. Appl. Environ. Microbiol. 61 (1): 397-398

Farber, J.M. and Idziak, E.S. (1984): Attachment of psychrotrophic meat spoilage bacteria to muscle surface. J. Food. Prot. 47: 92-95.

Frank, J.F.; Christen, G.L. and Bullerman, L.B. (1992): Microbiological count methods. p 275-276 in Standard Methods for Examination of Diary Products. $16^{\text {th }}$ ed. R.T. Marshall. Ed. American Public Health Association, Washington, D.C.

Gabriel-Piette, J.P. and Idziak, E.S. (1991): Role of flagella in adhesion of Pseudomonas fluorescence to tendon slices. Appl. Environ. Microbiol. 57: 1635-1639.

Gennari, M. and Dragotto, F. (1992): A study of the incidence of different fluorescent Pseudomonas species and biovars in the microflora of fresh and spoiled meat and fish, raw milk, cheese, soil and water. J. Appl. Bacteriol. 72(4): 281-288.

Gill, C.O. (2003): Active packaging in practice: Meat, p. 378-396. In H. Ahvenainem (ed.), Novel Food Packaging technology. 
Woodhead Publishing Limited and CRC Press LLC, Boca Raton, FL.

Gill, C.O. and Newton, K.G. (1982): The effect of lactic acid and concentration on the growth on meat of Gram-negative psychrotrophs from a meat work. Appl. Environ. Microbiol. 43: 284-288.

Gram, L.; Ravn, L.; Rasch, M.; Bruhn, J.B.; Christensen, A.B. and Givskov, M. (2002): Food Spoilage interaction between food spoilage bacteria. Int. J. Food Microbiol. 78: 79-97.

Harrigan, W.F. and McCance, M.E. (1966): Laboratory Methods in Microbiology, $3^{\text {rd }}$ ed. Academic Press, London, United Kingdom.

Jay, J.M. (1967): Nature, characteristics and proteolytic properties of beef spoilage Bacteria at low and high temperature. J. Appl. Microbiol. 15 (4): 943-944.

Jay, J.M. (2000): Food preservation with modified atmospheres, p. 283-295. In D.R. Heldman (ed.). Modern Food Microbiology. Aspen Publishers, Inc., Gaithersburg. Md.

Kohlmann, K.L.; Nielsen, S.S.; Steenson, L.R. and Ladisch, M.R. (1991): Production of proteases by psychrotrophic microorganisms. J.Dairy Sci. 74: 3275-3283.

Koutsoumanis, K.; Stamatiou, A.; Skandamis, P. and Nychas, J.G. (2006): Development of microbial model of temperature and $\mathrm{pH}$ on spoilage of ground beef and validation of the model under dynamic temperature condition. Appl. Environ. Microbiol. 72: 124-134.

Krieg, N. (1984): Bergey's Manual of Systemic Bacteriology, Volume 1. Baltimore: Williams\& Wilkins. ISBN 0683041088.

Labadie, J. (1999): Consequences of packaging on bacterial growth. Meat is an ecological niche. Meat Sci. 52:299-305

Lerke, P.; Faber, L. and Adams, R. (1967): Bacteriology of spoilage of fish muscle. IV- Role of protein. J. Appl. Microbiol. 15 (4): 770-776.

Marqués, S. and Ramos, J. (1993): Transcriptional control of the Pseudomonas putida TOL plasmid catabolic pathway. Mol. Microbiol. 9 (5): 923-929.

Marshall, R.T. (1993): Standard Methods for the Examination of Dairy Products, $16^{\text {th }}$ ed. American Public Health Association.

Mayer, D.; Margesin, R.; Klingsbichel, E.; Hartungen, E.; Jenewein, D.;

Schinner, F. and Märk, T.D. (2003): Rapid detection of meat spoilage by measuring volatile organic compounds by using 
proton transfer reaction mass spectrometry. Appl. Environ. Microbiol. 69: 4697-4705

Mead, G.C. and Adams, B.W. (1977): A selective medium for the rapid isolation of Pseudomonas associated with poultry meat spoilage. Br. Poult. Sci. 18: 661-670.

Molin, G. and Ternstrom, A. (1982): Numerical taxonomy of psychrotrophic Pseudomonads. J. Gen. Microbiol. 128: 1249-1264.

Morais, P.V.; Mesquita, C.; Andrade, J.L. and da Costa, M.S. (1997): Investigation of persistent colonization by Pseudomonas aeruginosa-like strain in a spring water bottling plant. App. Environ. Microbiol. 63: 851-856.

Palleroni, N.J. (1993): Pseudomonas classification. Antonie Leeuwenhock. 64: 231-251.

Payne, J.W. and Smith, W. (1994): Peptide transport by microorganisms. Adv. Microb. Physiol. 36: 1-80

Pererra, P.P.; Mathan, S.M.; Albert, P. and Baker, J. (1977): Aetiology of acute gastroenteritis in infancy and early childhood in southern India. Arch. Dis. Child. 52 (6) 482.

Prieto, M.; Garcís-Armesto, M.R.; García-López, M.L.; Alonso, C. and Otero, A. (1992): Species of Pseudomonas obtained at $7^{\circ} \mathrm{C}$ and $30^{\circ} \mathrm{C}$ during aerobic storage of lamb carcasses. J. Appl. Bacteriol. 73(4): 317-323.

Rice, D.; Ebel, E.; Hancock, D.; Besser, T.; Herriott, D. and Carpenter, L. (1997): Escherichia coli O157 in cull dairy cows on farm and at slaughter. J. Food Prot., 60 (11): 1386-1387.

Ryan, K.J. and Ray, C.G. (2004): Sherris Medical Microbiology, $4^{\text {th }}$ ed., McGraw Hill.

Sneath, P.H.A. and Sokal, R.R. (1973): Numerical taxonomy: the principles and practice of numerical classification. W. H. Freeman, San Francesco, Calif.

Sorhaug, T. and Stepaniak, L. (1997): Psychrotrophic and their enzymes in milk and dairy products: quality aspects. Trends Food Sci. Technol. 8:35-40.

Stanbridge, P.N. and Davies, A.R. (1998): The Microbiology of chillstored meat, P. 175-177. In A. Davies and R. Board (ed.), Microbiology of meat and poultry. Blackie Academic \& Professional London, United Kingdom.

Stanier, R.Y.; Palleroni, N.J. and Doudorhoff, M. (1966): The aerobic Pseudomonads: a taxonomic study. J. Gen. Microbiol. 43: 159-271. 
Tarrant, P.J.V.; Pearson. A.M.; Price, J.E. and Lechowich, R.V. (1971): Action of Pseudomonas fragi on the protein of pig muscle. Appl. Microbiol. 22 (2): 224-228.

Tsigarida, E. and Nychas, G.J.E. (2001): Ecophysiological attribution of Lactobacillus sp. and a Pseudomonas sp. on sterile beef fillets in relation to storage temperature and film permeability. J. Appl. Microbiol. 90:696-705.

Upmann, M.; Paulsen, P.; James, S. and Smulders, F.J.M. (2000): The microbiology of refrigerated meat. Fleishwirtschaft. 3: 38-45.

Vanderzant, C. and Splittstoesser, D.F. (1992): Compendium of Methods for the Microbiological Examination of Foods. American Public Health Association, Washington, D.C.

Widders, P.R.; Coates, K.J.; Warner, S.; Beattie, J.C.; Morgan, I.R. and Hickey, M.W. (1995): Controlling microbial contamination of beef and lamb meat during processing. Aust. Vet. J. 72: 208-211. 